\title{
A concise synthesis of the Lycopodium alkaloid cermizine D
}

Monica F. Enamorado, Colleen M. Connelly, Alexander Deiters, Daniel L. Comins*

North Carolina State University, Raleigh, NC 27695, USA

Keywords:

Alkaloid synthesis

Lycopodium alkaloids

Nitrogen heterocycles

1-Acylpyridinium salts

Asymmetric synthesis

ABSTRACT: A racemic and asymmetric synthesis of cermizine D (1) was accomplished in six steps from 4-methoxypyridine or 4-methoxy-3-TIPS-pyridine in $12 \%$ and $13 \%$ overall yield, respectively. A key step is a stereoselective 1,4-addition of a 2-((trimethylsilyl)methyl)pyridine-derived cuprate to a bicyclic 2,3-dihydro-4pyridone. Racemic and (-)-cermizine D failed to exhibit cytotoxicity against four different cell lines.

Cermizine D (1) is a cernuane-type Lycopodium alkaloid of the quinolizidine family. Along with cermizines A-C (Figure 1), cermizine D was isolated and structurally elucidated in 2004, by Kobayashi and collaborators from the club mosses Lycopodium cernuum and Lycopodium chinense. ${ }^{1}$ The same group performed bioactivity studies and reported that cermizine D (1) exhibited citotoxicity against murine lymphoma L1210 cells, with a IC 50 of $7.5 \mu \mathrm{g} / \mathrm{mL}(30 \mu \mathrm{M})$. Related cermizine alkaloids have attracted the attention of a number of laboratories. ${ }^{2}$

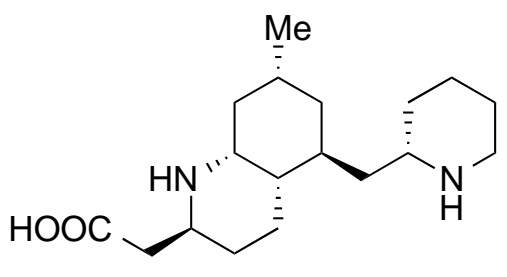

cermizine A

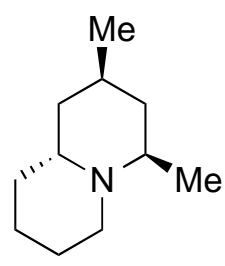

cermizine $\mathrm{C}$<smiles>CC1C[C@H](CC2CCCCN2)[C@H]2CCCN[C@@H]2C1</smiles>

cermizine B<smiles>C[C@H]1CCCN[C@@H](CC2CCCCN2)C1</smiles>

(-)-cermizine $\mathrm{D}, \mathbf{1}$

Figure 1. Structure of cermizines A-D. 
Interestingly, before the isolation of cermizine D in 2003, two diastereomers of the natural product $\mathbf{2}$ and $\mathbf{3}$ were synthesized (Figure 2) by Ayer ${ }^{3}$ in 1967, and by $\mathrm{Ban}^{4}$ in 1975, while both groups were pursuing the synthesis of dihydrodeoxyepiallocernuine (4).

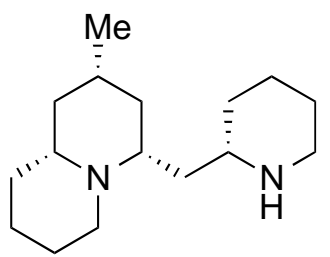

2<smiles>C[C@@H]1C[C@@H](CN2CCCCN2)CN2CCCC[C@@H]2C1</smiles>

3

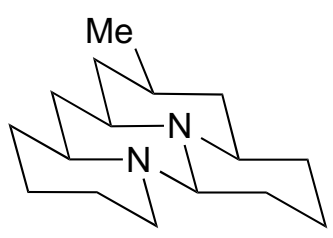

4

Figure 2. Dihydrodeoxyepiallocernuine (4) and diastereomers of cermizine D $(2,3)$.

The first asymmetric total synthesis of $(+)$-cermizine $D((+)-\mathbf{1})$ was reported by Takayama and coworkers in 2008, and consisted of an 18-step route featuring an oxazolidinone intermediate. ${ }^{5}$ Recently, in 2012, a second synthesis of (+)-1 including two different approaches, a cuprate addition strategy and a $\mathrm{PhSCH}_{2} \mathrm{I}$ alkylation pathway, 10 and 16 steps respectively, was published by Carter and collaborators. ${ }^{6}$ From these syntheses, the absolute stereochemistry of natural cermizine $\mathrm{D}$ can be assigned as (-)-1.

Our approach uses the bicyclic intermediate 6, which would be expected to undergo a metal-mediated conjugate addition of a nucleophilic 2-methyl piperidine precursor (Scheme 1). A Wittig olefination followed by two consecutive hydrogenations would complete the synthesis of cermizine D (1).

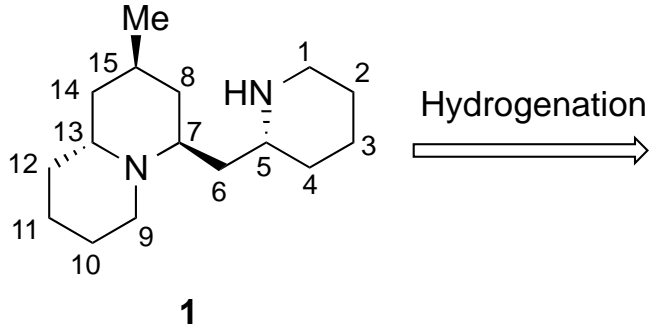<smiles>[R]C=CC(=O)[SnH2]</smiles>

$N$-acylpyridinium salt chemistry

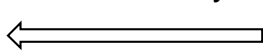<smiles>C[C@H]1C[C@@H]2CCCCN2[C@@H](Cc2ccccn2)C1</smiles>

a) 1,4-addition

b) 2 steps<smiles>O=C1C=CN2CCCCC2C1</smiles> 
Scheme 1. Retrosynthetic plan.

The known bicyclic dihydropyridone 6 was prepared in two steps (Scheme 2). Reaction of 4-methoxypyridine, phenyl chloroformate, and 4chlorobutylmagnesium bromide gave dihydropyridone 5, which on treatment with sodium methoxide provided 6 via a cleavage/cyclization sequence. ${ }^{7}$

The addition of 2-methylpyridine organometallics to enaminone $\mathbf{6}$ was studied. A number of metalation/transmetalation experiments were carried out in our screening for a suitable nucleophile. Initially, several reactions were conducted using the known 2-((tributylstannyl)methyl)pyridine ${ }^{8}$ as a nucleophile in the addition reaction to a preformed iminium salt formed from $\mathbf{6}$ and triflic anhydride. ${ }^{9}$ As a result, it was found that this transformation required low temperature in order to proceed without decomposition. After optimization, it was established that compounds $\mathbf{7 a}$, b could be obtained in $47 \%$ yield with a 3:1 diastereomeric ratio.

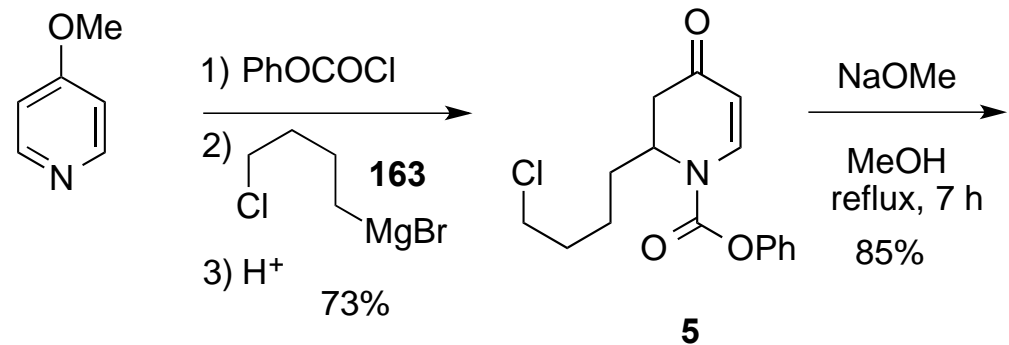<smiles>O=C1C=CN2CCCCC2C1</smiles>

1) $\mathrm{Tf}_{2} \mathrm{O}$

2)

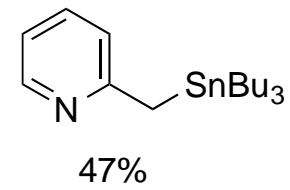<smiles>CCCCCCc1ccccn1</smiles>

dr 3:1

Scheme 2. Preparation of vinyl triflate 7 using an organotin reagent.

As a result of these experiments, it was decided to continue our screening to find a suitable nucleophile from 2-methylpyridine that could provide better selectivity in the addition reaction to 6 . First, we continued with the protocol of using a pre-formed iminium salt to facilitate the addition reaction, this time either TMSOTf or TIPSOTf was used to form the salt. ${ }^{10}$ A variety of organometallic reagents were prepared from the corresponding lithiated 2-methylpyridine and added to the pre-formed salt; however, there was little selectivity at the newly formed C-7 stereocenter. 
Continuing our search for better diastereoselectivity, and to solve some solubility restrictions encountered with the pre-formed salt strategy, a series of experiments were carried out using a modification of Taber's protocol for coppermediated conjugate addition of lithiated 2-methylpyridines to enones. ${ }^{2 \mathrm{e}} \mathrm{A}$ solution of enaminone $\mathbf{6}$ in THF was added to the Gilman cuprate 8, followed in most cases by addition of a Lewis acid (Scheme 3). When the Lewis acid was not present the addition reaction did not occur, regardless of the amount of organometallic used. When $\mathrm{BF}_{3} \bullet \mathrm{OEt}_{2}$ was added, the reaction proceeded only when 4.0 equivalents of the Lewis acid were employed; however, no selectivity was observed at C-7. Interestingly, when TMSCl was used as the Lewis acid, the best selectivity of all instances was found, $\mathrm{dr}=3.7: 1$. Nevertheless, this modest result seemed to be dependent on the nature of the copper salt employed.

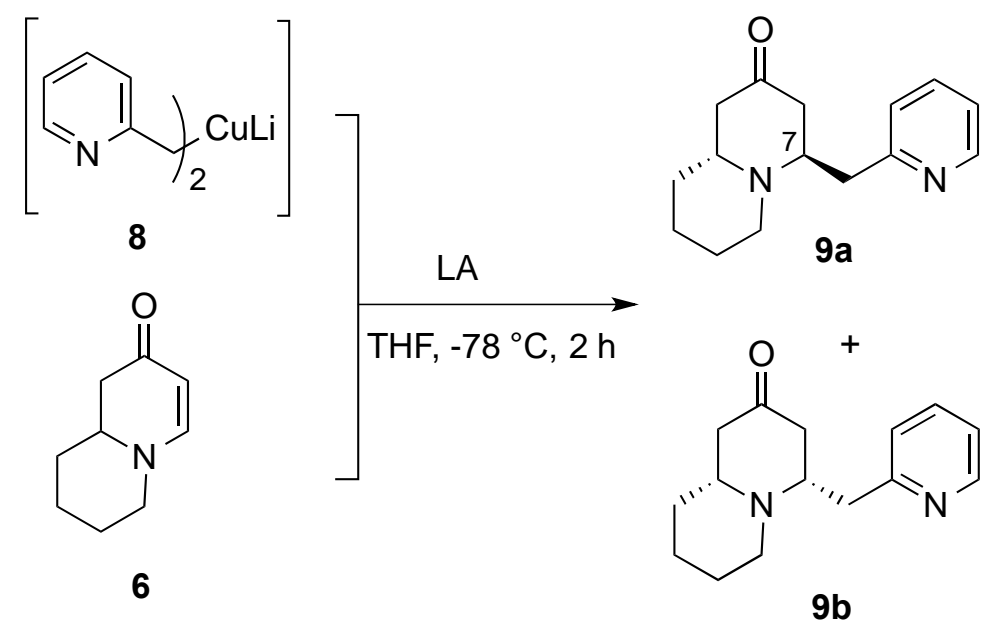

Scheme 3. Preparation of ketone 9a with in situ activation of enone 6.

Even though the best results obtained were comparable to the previous screening in terms of selectivity, the improved yields found were encouraging. Therefore, in our final tuning of this reaction, the Lewis acid activation of the carbonyl was preferred to the pre-formed salt approach, and $\mathrm{CuBr} \bullet \mathrm{SMe}_{2}$ was kept as the copper halide of choice. Additionally, the poor selectivity shown by the different organometallic reagents under study gave us enough data to believe that in order to improve the selectivity of this reaction, it was necessary to alter the nature of the non-selective cuprate 8 .

To this end, it was decided to introduce a substituent on the methyl group of 2methylpyridine that would cause some steric hindrance in the addition reaction, and that would be easy to remove on workup. Commercially available 2((trimethylsilyl)methyl)pyridine (10) was chosen as a potentially suitable starting material. 
Lithiation of $\mathbf{1 0}$ and addition of $\mathrm{CuBr} \cdot \mathrm{SMe}_{2}$ generated the dialkylcuprate $\mathbf{1 1}^{11}$ (Scheme 4). Moving to the addition reaction, the previously established best conditions using 8 were employed. To our delight, the use of 2((trimethylsilyl)methyl)pyridine (10) to prepare cuprate $\mathbf{1 1}$ proved to be an excellent choice, since the conjugate addition reaction proceeded in good yield and with full stereoselectivity to afford the sought after diastereomer 9a. Reaction workup with aqueous ammonium fluoride converted the silyl enol ether of the intermediate $\mathbf{1 2}$ to the desired C- 15 carbonyl and also cleaved the TMS group at C-6 to give 9a. After this encouraging result, the manipulation of the C-15 carbonyl was explored.

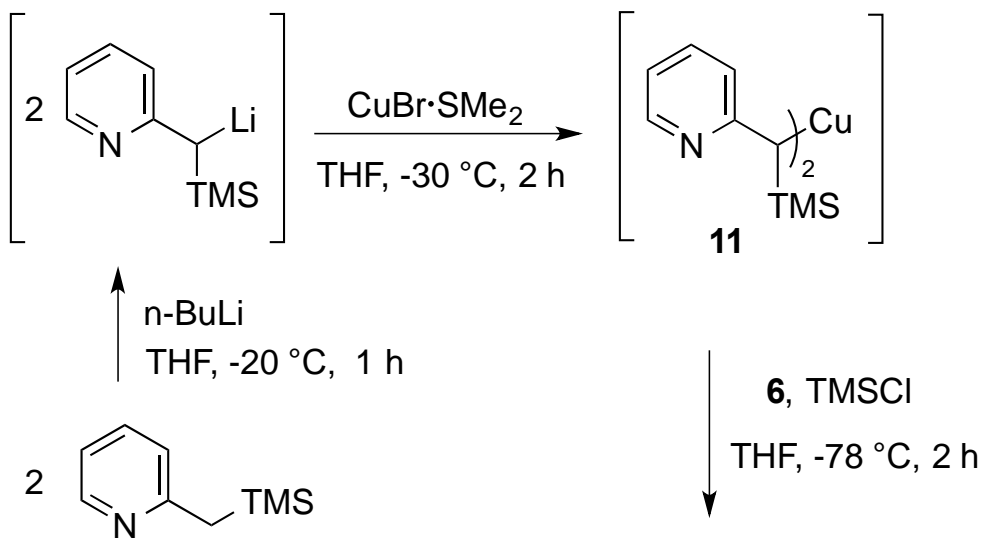

10
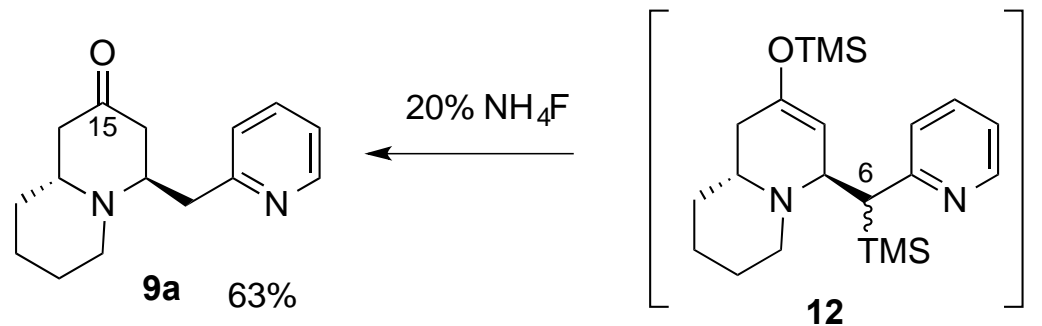

Scheme 4. Conjugate addition using 2-((trimethylsilyl)methyl)pyridine (10).

For the next step a Wittig olefination was used for installation of the last carbon in the target molecule at $\mathrm{C}-15$. This conversion went smoothly providing the alkene 13 in 98\% yield (Scheme 5). Following our retrosynthetic plan, the last two steps would involve consecutive hydrogenations to obtain the natural product, cermizine D (1). 

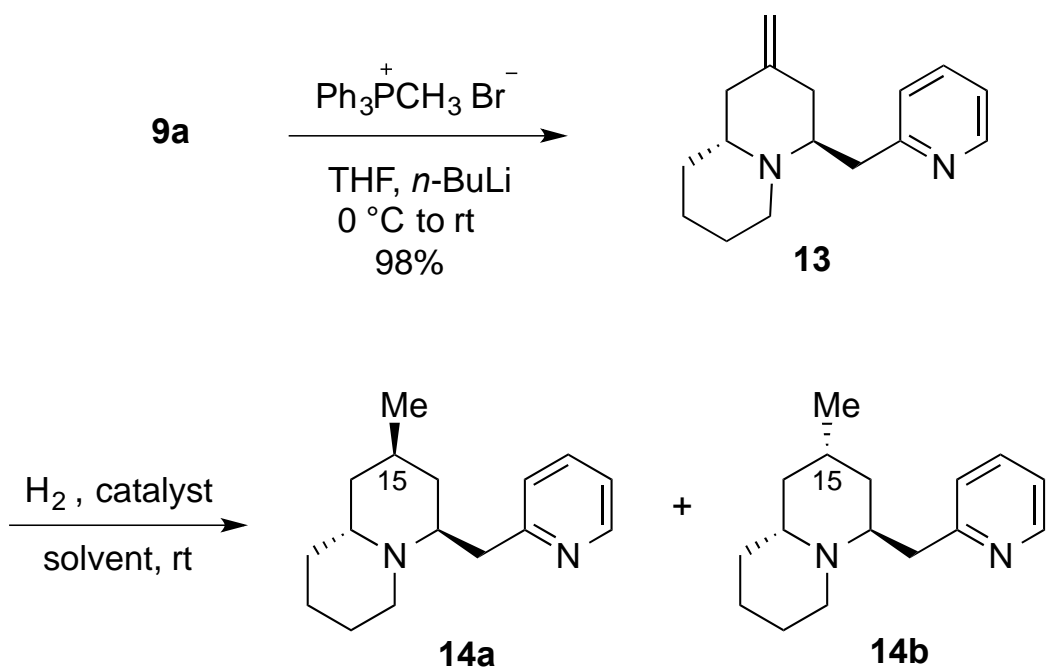

Scheme 5. Wittig reaction of $9 \mathrm{a}$ and olefin reduction.

Several hydrogenation conditions for reduction of $\mathbf{1 3}$ were examined. The use of Wilkinson's catalyst resulted in the recovery of starting material. Both, Raney-Ni and $\mathrm{Pd}(\mathrm{OH})_{2}$ on carbon gave diastereomer $\mathbf{1 4 b}$ as the major product $(>10: 1)$, in good yield. Interestingly, when Pt/C in EtOAc was used, the selectivity was reversed, and compound 14a was the major diastereomer obtained in $68 \%$ yield. These results were captivating, since not only the natural product but the C-15 epimer of cermizine D (2) could be accessed without difficulty using simple hydrogenation reactions.

In order to complete the synthesis of (+/-)-cermizine D (1), the last step required the reduction of the pyridine ring to the corresponding piperidine. Methods for the diastereo- or enantioselective hydrogenation of unactivated 2alkylpyridines are underdeveloped. ${ }^{2 \mathrm{~g}}, 12$ For non-asymmetric hydrogenations, the catalyst of choice for this type of transformation is $\mathrm{PtO}_{2}$ in acetic acid. Using these standard conditions, cermizine D (1) and C5-epi-cermizine D (15) were obtained in 92\% yield as a separable 1:1 mixture of isomers (Scheme 6). Spectral data of our racemic $\mathbf{1}$ are in agreement with those published. 


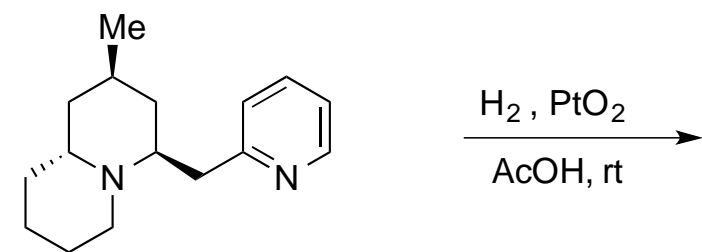

$14 a$<smiles>CC1CCN[C@@H](CC[C@@H]2C[C@H](C)C[C@@H]3CCCCN32)C1</smiles>

Cermizine D, 1 (46\%)<smiles>O=[W]C1C[C@@H]2CCCCN2[C@@H](CC2CCCCN2)C1</smiles>

C5-epi-cermizine D, 15 (46\%)

\section{Scheme 6.}

The first asymmetric synthesis of (-)-cermizine D was accomplished by using our reported method to prepare enantiopure intermediate 6 , which was previously used in our synthesis of $(+)$-subcosine I.7b The rest of the synthesis followed the steps described above for the preparation of $( \pm)-\mathbf{1}$ from racemic 6 (Scheme 7). Our synthetic (-)-cermizine $\mathrm{D}$ exhibited an optical rotation in agreement with reported data $\left[[\alpha]^{25} \mathrm{D}-15.2\right.$ (c 0.1, MeOH); TFA salt: $\operatorname{lit}^{1}[\alpha]^{25} \mathrm{D}-33(c 0.6, \mathrm{MeOH}) ; \operatorname{lit}^{6}((+)-1)$ $[\alpha]{ }^{20} \mathrm{D}+40.8(c$ 0.9, $\left.\mathrm{MeOH})\right]$.<smiles>COc1ccncc1[In]S</smiles>

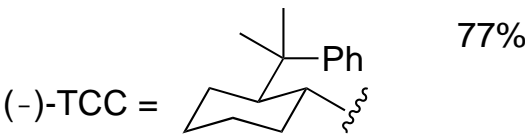<smiles>COC(OC)[R6](=O)(=O)OC</smiles>

1. ( )-TCCOCOCl, toluene, $-42^{\circ} \mathrm{C}$

2)<smiles>ClCCCC(Br)Br</smiles>

3) $\mathrm{H}^{+}$

$77 \%$<smiles>O=C1C=CN2CCCC[C@H]2C1</smiles>

6<smiles>CC(C)(F)[O+]C(=O)N1C=C([In]S)C(=O)C[C@H]1CCCCCl</smiles>

16

\section{Scheme 7.}

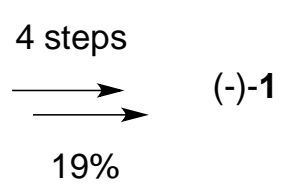


In summary, racemic and (-)-cermizine D (1) were synthesized in six steps via $\mathrm{N}$-acylpyridinium salt chemistry starting from 4-methoxypyridine or 4-methoxy-3TIPS-pyridine in $12 \%$ and $13 \%$ yields, respectively. Conjugate addition of 6 with Gilman cuprate $\mathbf{1 1}$ in the presence of TMSCl and workup with $\mathrm{NH}_{4} \mathrm{~F}$ provided $9 \mathbf{a}$ as one diastereomer. A Wittig olefination of ketone 9a gave the corresponding olefin 13 and two subsequent hydrogenations delivered the natural product (-)-cermizine D (1) with an overall yield of $13 \%$, along with C5-epi-cermizine D (15).

Contrary to published results, ${ }^{1}$ racemic and (-)-cermizine D failed to exhibit cytotoxicity against four different cell lines including LI210.13

\section{Acknowledgments}

NMR and mass spectra were obtained at NCSU Instrumentation laboratories, which were established by grants from North Carolina Biotechnology Center and National Science Foundation (Grant No. CHE-0078253). MFE. thanks NCSU for a North Carolina State University Diversity Enhancement Grant.

\section{Supplementary material}

Supplementary material associated with this article can be found in the online version at

\section{References and notes}

1. Morita, H.; Hirasawa, Y.; Shinzato, T.; Kobayashi, J. Tetrahedron 2004, 60, 70157023.

2. (a) Snider, B. B.; Grabowski, J. F. J. Org. Chem. 2007, 72, 1039-1042. (b) Cui, L.; Peng, Y.; Zhang, L. J. Am. Chem. Soc. 2009, 131, 8394-8395. (c) Beng, T. K.; Gawley, R. E. J. Am. Chem. Soc. 2010, 132, 12216-12217. (d) Cheng, G.; Wang, X.; Su, D.; Liu, H.; Liu, F.; Hu, Y. J. Org. Chem. 2010, 75, 1911-1916. (e) Taber, D. F.; Guo, P.; Pirnot, M. T. J. Org. Chem. 2010, 75, 5737-5739. (f) Chou, S. -S. P.; Chung, Y. -C.; Chen, P. A.; Chiang, S. -L.; Wu, C. -J. J. Org. Chem. 2011, 76, 692-695. (g) Bradshaw, B.; LuqueCorredera, C.; Bonjoch, J. Chem. Commun. 2014, 50, 7099-7102 and references cited therein. 
3. Ayer, W. A.; Piers, K. Can. J. Chem. 1967, 45, 451-459.

4. Ban, Y.; Kimura, M.; Oishi, T. Chem. Pharm. Bull. 1976, 24, 1490-1496.

5. (a) Nishikawa, Y.; Kitajima, M.; Takayama, H. Org. Lett. 2008, 10, 1987-1990. (b) Nishikawa, Y.; Kitajima, M.; Kogure, M.; Takayama, H. Tetrahedron 2009, 65, 16081617.

6. Veerasamy, N.; Carlson, E. C.; Carter, R. G. Org. Lett. 2012, 14, 1596-1599.

7. (a) Al-awar, R. S.; Joseph, S. P.; Comins, D. L. J. Org. Chem. 1993, 58, 7732-7739.

(b) Comins, D. L.; LaMunyon, D. H. J. Org. Chem. 1992, 57, 5807-5809. (c) For other syntheses of 6, see: Niphakis, M. J.; Turunen, B. J.; Georg, G. I. J. Org. Chem. 2010, 75, 6793-6805 and references cited therein.

8. Sosabowski, M. H.; Powell, P. J. Chem. Research (S) 1997, 12-13.

9. (a) Beaulieu, E. D., Voss, L.; Trauner, D. Org. Lett. 2008, 10, 869-872. (b) Tsukanov, S. V.; Comins, D. L. J. Org. Chem. 2014, 79, 9074-9085.

10. Donohoe, T. J.; Brian, P. M.; Hargaden, G. C.; O’Riordan, T. J. C. Tetrahedron 2010, $66,6411-6420$.

11. For preparation of the corresponding monoalkyl copper complex, see: Papasergio, R. I.; Raston, C. L.; White, A. H. J. Chem. Soc., Dalton Trans. 1987, 3085-3091.

12. Ye, Z.-S.; Chen, M.-W.; Chen, Q.-A.; Shi, L.; Duan, Y.; Zhou, Y.-G. Angew. Chem. Int. Ed. 2012, 51, 10181-10184.

13. See supplementary material for details. 